\title{
Pelatihan Penggunaan Google Meet dan Google Classroom bagi Dosen Tidak Tetap Universitas Kristen Wira Wacana Sumba
}

Mayun Erawati Nggaba*1, Erwin Randjawali2, Yuliana Tamu Ina Nuhamara ${ }^{3}$, Anggriati Ledu Ngaba ${ }^{4}$, Mega Retno Wulandari5, Darius Imanuel Wadu ${ }^{6}$, Itha Priyastiti ${ }^{7}$, Elsy S H Taunu ${ }^{8}$, Stevvileny Angu Bima ${ }^{9}$, Iona Lisa Ndakularak ${ }^{10}$, Yuliana S Eko ${ }^{11}$, Irna Natalis Sanit ${ }^{12}$

1,2,3,4,5,6,7,8,9,10,11,12 Universitas Kristen Wira Wacana Sumba, Waingapu, Indonesia *Corresponding Author: mayun@unkriswina.ac.id

\begin{abstract}
Info Artike1 Diterima : 21/11/2021 Direvisi: 23/11/2021 Disetujui: 25/11/2021
Abstract. Universitas Kristen Wira Wacana Sumba is one of the universities that organizes online learning. This happened as a result of the COVID-19 pandemic. This situation requires all lecturers to be able to conduct online learning by utilizing the available facilities, namely Google Classroom and Google Meet, both permanent and adjunct lecturers. Permanent lecturers have used the application since the beginning of the covid-19 pandemic, while adjunct lecturers who held lessons this semester have never used the Google Classroom and Google Meet applications. If this is allowed, then learning will not be held properly. Therefore, this training is carried out in several stages, namely analyzing the needs of non-permanent lecturers, implementing activities, and following up. This training makes the online learning by adjunct lecturers can be carried out properly. Based on the results of the follow-up, the participants proposed further training on the use of Google Classroom, especially in making assignment assessment rubrics and quizzes.
\end{abstract}

Keywords: Online learning, Google Classroom, Google Meet

\begin{abstract}
Abstrak. Universitas Kristen Wira Wacana Sumba merupakan salah satu perguruan tinggi yang menyelenggarakan pembelajaran secara daring. Hal ini terjadi sebagai dampak pandemic covid-19. Tentunya keadaan ini mengharuskan semua dosen dapat menyelenggarakan pembelajaran secara daring dengan memanfaatkan fasilitas yang tersedia yaitu Google Classroom dan Google Meet, baik dosen tetap maupun dosen tidak tetap. Dosen tetap telah menggunakan aplikasi tersebut sejak awal pandemic covid-19, sedangkan dosen tidak tetap yang menyelenggarakan pembelajaran pada semester gasal 2021/2022 belum pernah menggunakan aplikasi Google Classroom dan Google Meet. Jika hal ini dibiarkan, maka akan berdampak pada mata kuliah yang diampu dan pembelajaran tidak akan berjalan dengan optimal. Oleh karena itu, pelatihan ini dilakukan dengan beberapa tahapan yaitu analisis kebutuhan dosen tidak tetap, pelaksanaan pelatihan, dan follow up. Dengan adanya pelatihan ini, pembelajaran daring oleh dosen tidak tetap dapat terlaksana dengan baik. Berdasarkan hasil follow up, ketiga peserta PkM mengajukan adanya pelatihan lanjutan terkait penggunaan Google Classroom, secara khusus dalam pembuatan rubrik penilaian tugas dan kuis.
\end{abstract}

Kata Kunci: pembelajaran daring, Google Classroom, Google Meet.

How to Cite: Nggaba, M. E., Randjawali, E., Nuhamara, Y. T. I., Ngaba, A. L., Wulandari, M. R., Wadu, D. I., Priyastity, I., Taunu, E. S.H., Bima, S. A., Ndakularak, I. L., Eko, Y. S., \& Sanit, I. N. (2021). Pelatihan Penggunaan Google Meet dan Google Classroom bagi Dosen Tidak Tetap Universitas Kristen Wira Wacana Sumba. Prima Abdika: Jurnal Pengabdian $213-218$. https://doi.org/10.37478/abdika.v1i4.1361

Copyright (c) 2021 Mayun Erawati Nggaba, Erwin Randjawali, Yuliana Tamu Ina Nuhamara, Anggriati Ledu Ngaba, Mega Retno Wulandari, Darius Imanuel Wadu, Itha Priyastiti, Elsy $S H$ Taunu, Stevvileny Angu Bima, Iona Lisa Ndakularak, Yuliana S Eko, Irna Natalis Sanit. This work is licensed under a Creative Commons Attribution-ShareAlike 4.0 International License.

\section{Pendahuluan}

Salah satu permasalahan yang dihadapi oleh Universitas Kristen Wira Wacana (Unkriswina) Sumba adalah perubahan metode pembelajaran dari tatap muka menjadi pembelajaran online maupun metode pembelajaran lainnya. Perubahan bentuk metode pembelajaran ini dikarenakan adanya pandemi Virus Corona yang juga melanda Indonesia. Oleh karena itu, Rektor Unkriswina Sumba melalui Surat Edaran No. 012/EDR-R/2020 memutuskan untuk menggantikan bentuk Kegiatan Belajar Mengajar (KBM) di Unkriswina dengan metode $\mathrm{KBM}$ daring atau metode pembelajaran lainnya, sehingga 
proses pembelajaran serta aktivitas kantor dilaksanakan di rumah setiap civitas akademik Unkriswina Sumba (Work from Home). Hal ini untuk mendukung program pemerintah dalam rangka pencegahan penyebaran virus Corona 19, seperti yang tertuang dalam Surat Edaran Menteri Pendayagunaan Aparatur Negara dan Reformasi Birokrasi No. 19 Tahun 2020 tentang Penyesuaian Sistem Kerja Aparatur Negara dalam Upaya Pencegahan Penyebaran Covid-19 di Lingkungan Instansi Pemerintah.

Para dosen di Unkriswina Sumba, baik dosen tetap maupun dosen tidak tetap, tetap melaksanakan proses pembelajaran pada masa pandemik Covid-19 melalui pembelajaran online. Sehingga, meskipun tidak terjadi aktivitas perkuliahan secara tatap muka, namun dosen dan mahasiswa tetap dapat berinteraksi secara online. Proses pembelajaran yang dilakukan pun bervariasi, dan memanfaatkan aplikasi pembelajaran online yang bervariasi, seperti: WhatsApp, google class room, google meet, youtube, zoom, portal ecampuz (telah disediakan oleh Unkriswina Sumba sejak 2017), e-mail, dan lain-lain. Hal ini didukung oleh beberapa penelitian sebelumnya yang menyatakan bahwa pembelajaran online dapat menunjang proses pembelajaran Matematika. Misalnya, penggunaan google class room dapat meningkatkan motivasi belajar mahasiswa (Nurbaeti, 2019), sehingga dapat digunakan untuk matakuliah Matematika dan lain-lain (Utami, 2019).

Namun, pembelajaran daring menjadi suatu permasalahan ketika dosen menemukan kesulitan dalam pelaksanaannya. Hal ini terjadi pada dosen tidak tetap Unkriswina Sumba tahun akademik 2021/2022. Permasalahan terjadi karena dosen tidak tetap belum pernah menyelenggarkan pembelajaran secara daring dengan memanfaatkan aplikasi yang tersedia yang secara umum digunakan oleh Unkriswina Sumba, yaitu Google Classroom dan Google Meet. Padahal, Pujiyanti (2021), pembelajaran daring atau pembelajaran jarak jauh dapat berjalan lancar dan baik jika media pembelajaran online digunakan secara efektif. Selain itu, Hikmat, dkk (2020) juga menyatakan bahwa efektivitas metode pembelajaran merupakan suatu ukuran yang berhubungan dengan tingkat keberhasilan dari suatu proses pembelajaran.

Berdasarkan permasalahan dosen tidak tetap Unkriswina Sumba, maka program studi Pendidikan Matematika Unkriswina Sumba melakukan kegiatan pelatihan kepada dosen tidak tetap tahun akademik 2021/2022. Pelatihan yang dilakukan berupa pelatihan penggunaan Google Classroom dan Google Meet. Pelatihan ini diharapkan dapat meningkatkan pengetahuan dan keterampilan dosen tidak tetap dalam menggunakan Google Meet dan Google Classroom sehingga pembelajaran daring dapat terlaksana dengan baik dan optimal.

Website resmi Google menyatakan bahwa aplikasi Google Classroom merupakan aplikasi yang daapt diperoleh secara gratis yang terdiri dari email, dokumen dan penyimpanan yang didesain untuk memudahkan pendidik dalam mengelola kelas, menghemat waktu, dan meningkatkan komunikasi dengan peserta didik. Brock (2015: 25), manfaat Google Classroom diantaranya mudah dalam persiapan kelas, peserta didik dan asisten pengajar 
dapat diundang ke dalam kelas; dapat menghemat kertas dan waktu; pemberian tugas, berkomunikasi dan pengelolaan kelas dalam satu tempat; semua materi otomatis tersimpan dalam folder Google Drive; dan aman dan terjangkau. Sejalan dengan itu, Nurdin (2019), penerapan google classroom sangat bermanfaat terutama untuk pengumpulan tugas secara daring. Hasil penelitian Pratama (2016) juga menyebutkan bahwa terdapat pengaruh penggunaan google classroom terhadap efisiensi pemanfaatannya.

\section{Metode Pelaksanaan}

Kegiatan pengabdian ini dilakukan dengan beberapa tahapan berikut.

\section{a. Analisis Kebutuhan}

Pada langkah ini dilakukan analisis kebutuhan dan situasi mitra PkM. Analisis ini dilakukan dengan teknik wawancara dengan 3 orang dosen tidak tetap. Hasil wawancara adalah kurangnya pengetahuan ketiga dosen tidak tetap dalam menggunakan Google Meet dan Google Classroom. Berdasarkan hasil analisis kebutuhan, solusi yang dapat diberikan adalah pelatihan penggunaan Google Meet dan Google Classroom.

\section{b. Pelatihan Penggunaan Google Meet dan Google Classroom}

Dengan adanya pelatihan ini, diharapkan ketiga dosen tidak tetap dapat menggunakan Google Meet dan Google Classroom dengan optimal agar pelaksanaan pembelajaran daring terlaksana dengan baik. Adapun materi yang disampaikan dalam pelatihan ini adalah:

1) Cara menggunakan Google Meet, dengan tujuan agar dosen dapat menggunakan Google Meet serta fitur-fiturnya dalam pelaksanaan pembelajaran daring;

2) Cara menggunakan Google Classroom, dengan tujuan agar dosen dapat menggunakan Google Classroom serta fitur-fiturnya dalam mengelola pembelajaran, secara khusus dalam pengelolaan berkas tugas, ujian, dan materi perkuliahan.

\section{c. Follow Up}

Pada tahapan ini dilakukan follow up terhadap ketiga dosen tidak tetap terkait pelatihan yang telah diikuti dan pembelajaran daring yang telah dilakukan oleh dosen tersebut.

\section{Hasil dan Pembahasan}

Pelatihan ini dilakukan kepada tiga dosen tidak tetap Fakultas Keguruan dan Ilmu Pendidikan Universitas Kristen Wira Wacana Sumba yang merupakan dosen baru dan dilakukan di Kampus Universitas Kristen Wira Wacana Sumba pada tanggal 25 September 2021. 
Sebelum pelatihan penggunaan Google Meet dan Google Classroom dilakukan, tim PkM terlebih dulu melakukan analisis kebutuhan kepada tiga dosen tidak tetap terkait pembelajaran daring. Hasil wawancara menunjukkan bahwa ketiga dosen tersebut belum pernah menggunakan aplikasi Google Meet dan Google Classroom. Tentunya hal ini akan berdampak pada pembelajaran yang akan dilaksanakan. Oleh karena itu, tim PkM memberikan solusi terkait permasalahan ini yaitu diadakannya pelatihan penggunaan Google Meet dan Google Classroom, serta fitur-fitur yang tersedia.

Pelaksanaan pelatihan ini terdiri atas dua bagian yaitu penyampaian materi dan praktik langsung oleh dosen. Pada tahapan penyampaian materi, tim PkM memaparkan materi terkait pembuatan akun Google Classroom, membuat kelas di Google Classroom, menggunggah materi dan tugas di Google Classroom, dan membuat rapat di Google Meet, serta sinkronisasi dengan fitur lainnya yang tersedia. Metode yang digunakan dalam pemaparan materi adalah metode ceramah dan tanya jawab secara langsung. Setelah pemaparan materi selesai dilakukan, peserta diminta untuk mempraktikkan langsung penggunaan Google Meet dan Google Classroom yang telah diajarkan. Alokasi waktu pelatihan ini terlihat pada Tabel 1.

Tabel 1. Alokasi waktu pelatihan

\begin{tabular}{cc}
\hline Kegiatan & Alokasi Waktu \\
\hline Pembukaan & 5 menit \\
Penyampaian Materi & 45 menit \\
Praktik Langsung oleh Peserta & 60 menit \\
Penutupan & 5 menit \\
\hline
\end{tabular}

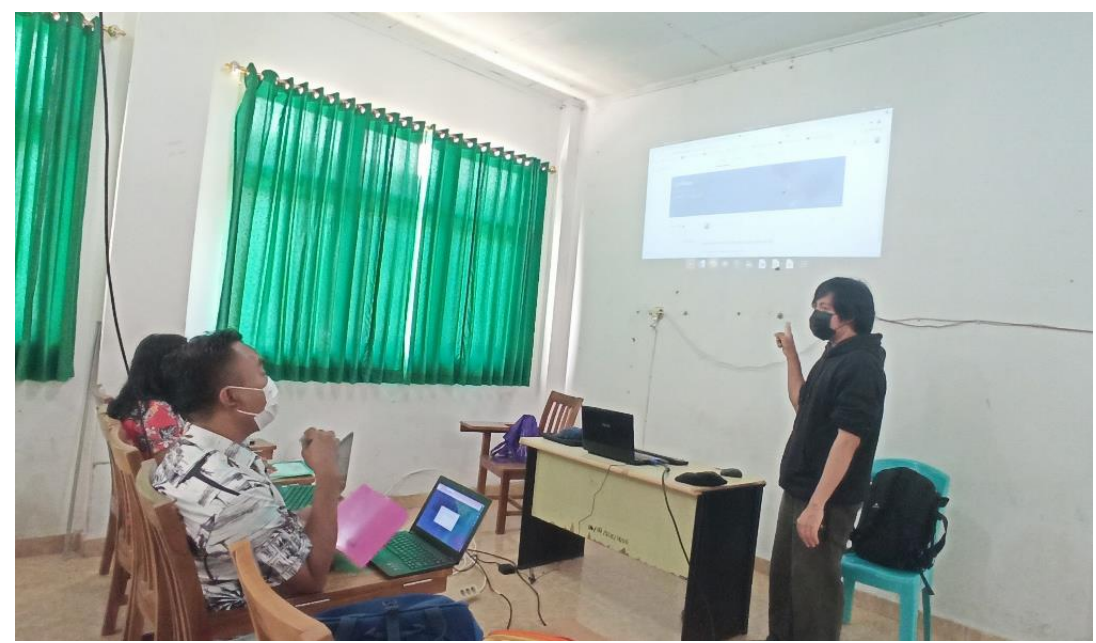

Gambar 1. Penyampaian materi oleh tim PkM 


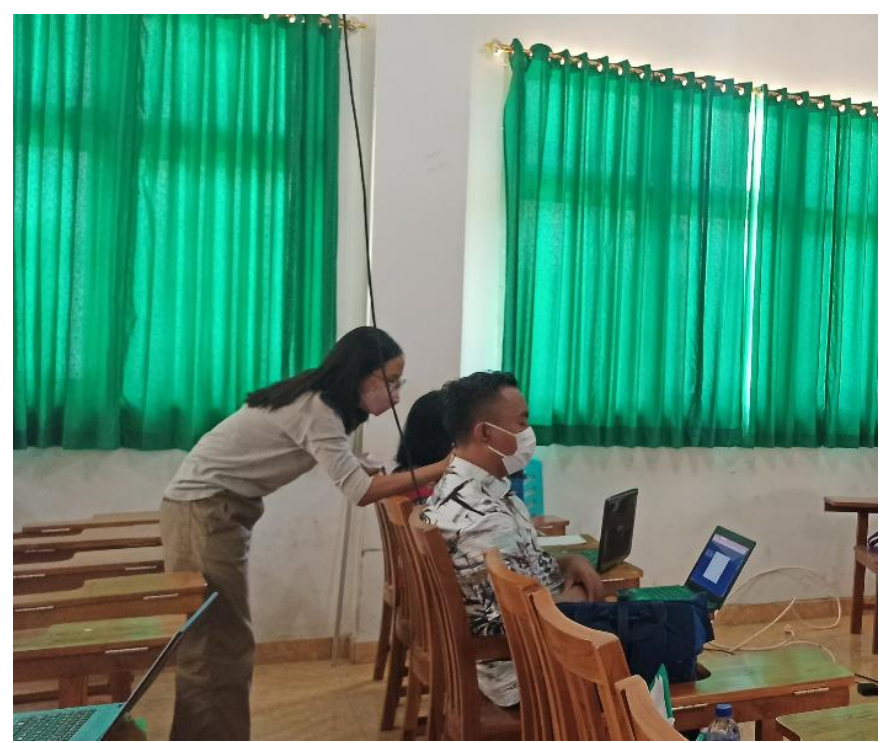

Gambar 2. Pendampingan langsung oleh tim $P k M$

Gambar 1 dan Gambar 2 menunjukkan pelatihan yang dilakukan oleh tim. Penyampaian materi Google Classroom dan Google Meet terlihat pada Gambar 1, sedangkan pada Gambar 2 pendampingan langsung oleh tim terkait praktik langsung penggunaan Google Classroom dan Google Meet. Berdasarkan hasil follow up, peserta $\mathrm{PkM}$ dapat menggunakan dan memanfaatkan Google Classroom dan Google Meet dengan baik sehingga perkuliahan terlaksana dengan baik. Peserta PkM juga mengajukan permintaan adanya tindak lanjut dari kegiatan ini yaitu pendampingan pembuatan rubrik tugas dan kuis.

\section{Simpulan dan Tindak Lanjut}

Pelatihan Google Meet dan Google Classroom yang dilakukan oleh Tim PkM telah meningkatkan pengetahuan dan keterampilan ketiga dosen tidak tetap FKIP Universitas Kristen Wira Wacana Sumba sehingga pembelajaran yang dilakukan secara daring dapat terlaksana dengan baik. Berdasarkan hasil follow up, ketiga peserta PkM mengajukan adanya pelatihan lanjutan terkait penggunaan Google Classroom, secara khusus dalam pembuatan rubrik penilaian tugas dan kuis.

\section{Daftar Pustaka}

Brock. (2015). Introduction to Google Classroom: An Easy-ToUse Guide to Taking Your Classroom Digital. Createspace Independent Publishing Platform.

Hikmat, Hermawan, Aldim, and Irwandi. (2020). Efektivitas Pembelajaran Daring Selama Masa Pandemi Covid-19: Sebuah Survey Online. Karya Tulis Imiah (KTI) Masa Work from Home (WFH) Covid-19 UIN Sunan Gunung Djati Bandung. Diakses 20 November 2021 pada http://digilib.uinsgd.ac.id/30625/1/FISIP\%20Kelompok\%207.pdf

Nurbaeti, N. (2019). Pengaruh media pembelajaran google classroom dalam pembelajaran analisis real terhadap motivasi belajar mahasiswa. Jurnal 
Penelitian Matematika dan Pendidikan Matematika, 2(1), 50-59. https://e-journal.my.id/proximal/article/view/211.

Nurdin, S. (2019. Pemahaman Google Classroom Peserta Diklat Subtantif Peningkatan Kompetensi Multimedia di Kementerian Agama Kabupaten Tasikmalaya. Jurnal Balai Diklat Keagamaan Bandung, 13(2), 134-141, ISSN: 2085-4005

Pratama, D. (2016). Analisis Pengaruh Pemanfaatan Google Classroom Terhadap Efisiensi Pada STMIK, 16, 251-254. Retrieved from http:/ / ci.nii.ac.jp/naid/40020776815/

Pujiyanti, D. I. M. (2021). Pelatihan Penggunaan Media Pembelajaran Berbasis Online Bagi Guru Terdampak Covid-19 di SMPN 126 Jakarta. Jurnal Solma, 10 , $170-178$. https://journal.uhamka.ac.id/index.php/solma/article/view/5028/227 2.

Utami, R. (2019). Analisis Respon Mahasiswa terhadap Penggunaan Google Classroom pada Mata Kuliah Psikologi Pembelajaran Matematika. Prosiding Seminar Nasional Matematika, 2, 498-502. Retrieved from https://journal.unnes.ac.id/sju/index.php/prisma/ ISSN. 